\title{
МЕХАНІЗМИ ІННОВАЦІЙНОЇ ВЗАСМОДІЇ СУБ'ЄКТІВ ГОСПОДАРЮВАННЯ В КОНТЕКСТІ ТРАНСФОРМАЦІЇ ЕКОНОМІКИ ЗНАНЬ
}

\author{
DOI: $10.32620 /$ cher.2020.4.06
}

Постановка проблеми. Успіх функціонування сучасного бізнесу залежить не стільки від ефективного використання природних ресурсів, скільки від плодотворної взаємодії між суб'єктами господарювання та своєчасного отримання необхідної інформації щодо розроблення та впровадження у виробництво новітніх технологій, що викликає необхідність пошуку більш досконалих механізмів інноваційної взаємодії суб'єктів господарювання в умовах постійної трансформації отриманих знань. Мета дослідження спрямована на розробку інноваційних механізмів взаємодії суб'єктів господарювання шляхом отримання нових знань в процесі трансформації економіки. Методологічною основою дослідження стали сучасні нормативно-правові та законодавчі аспекти здійснення інноваційної діяльності. В проведених дослідженнях використані методи діалектики, способи і принципи наукового пізнання, інструменти економічного аналізу для удосконалення механізмів інноваційної взаємодії, отримання новітньої інформації та знань суб'єктами господарювання. Основною гіпотезою дослідження стало припущення щодо можливості удосконалення механізму сучасної взаємодії суб'єктів господарювання шляхом зацікавленого об єднання усіх наявних ресурсів, в тому числі інтелектуальних, для розв'язання нагальних регіональних і національних проблем. Виклад основного матеріалу. У статті досліджуються принципи здійснення інноваційної діяльності та означені головні аспекти, на яких грунтується взаємодія суб'єктів господарювання в умовах постійної трансформації наявних знань. Проаналізовані основні показники, що характеризують рівень інноваційних досягнень та обгрунтовані заходи щодо ефективної взаємодії суб'єктів господарювання. Оригінальність та практична значимість дослідження підтверджується запропонованим удосконаленим механізмом взаємодії суб’єктів господарювання, що базується на певному рівні здійснених інноваційних трансформацій усіх взаємодіючих інституцій та спрямований на досягнення загально національних, регіональних цілей і стратегій розвитку, виходячи 3 тих глобальних викликів, що спонукають вирішувати загальносвітові людські проблеми. Висновки та перспективи подальших досліджень. Доведено, що інноваційні механізми взаємодії суб'єктів господарювання мають включати: економічні стимули щодо заохочення ефективної взаємодії суб’єктів господарювання; інноваційні стратегії ініціювання заходів об єднання різних компаній та інституцій; реформи у освітній діяльності щодо безперервного навчання протягом реального життєвого циклу діяльності суб'єктів господарювання; розгалужену інфраструктуру, що має стабільні комунікаційні зв'язки; проспект надання інтелектуальних послуг, що визначають рівень інноваційних знань людського капіталу. Подальші дослідження будуть спрямовані на налагодження та удосконалення партнерських відносин, зв’язків та комунікацій між різними суб'єктами господарювання.

Ключові слова:

суб'єкти господарювання, економіка знань, інновації, механізм взаємодії, трансформація.

\section{MECHANISMS OF INNOVATIVE CO-OPERATION OF BUSINESS SUBJECTS IN THE CONTEXT OF TRANSFORMATION OF KNOWLEDGE ECONOMY}

Raising of problem. The success of modern business depends not so much from the efficient use of natural resources, but from the fruitful communication between business subjects and timely receipt of the necessary information on the development and implementation of new technologies, which necessitates finding better mechanisms for innovative co-operation of business subjects in conditions of constant transformation of the received knowledge. A research aim is developing the innovative mechanisms for the co-

${ }^{1}$ Калінеску Тетяна Василівна, д-р екон. наук, професор, завідувач кафедри фінансів, обліку і оподаткування, Національний аерокосмічний університет ім. М. С. Жуковського «Харківський авіаційний інститут», м. Харків, Україна.

Calinescu Tetyana, Doctor of Economic Sciences, Professor, Head of Finance, Accounting and Taxation Department, National Aerospace University «Kharkiv Aviation Institute», Kharkiv, Ukraine.

ORCID ID: 0000-0003-4919-5788

e-mail: tetyana.calinescu@gmail.com 
operation of e business subjects by gaining new knowledge in the process of economic transformation. The methodological basis of research was modern regulatory and legislative aspects of innovation. The research uses dialectical methods, methods and principles of scientific knowledge, tools of economic analysis for improve the mechanisms of innovative communication, obtaining the latest information and knowledge of business subjects. The basic hypothesis of research was the assumption of the possibility of improving mechanism of modern communication of e business subjects by interested in combining all available resources, including intellectual, to solve pressing regional and national problems. Exposition of basic material. In the article examines the principles of innovation and identifies the main aspects on which the communication of business subjects in the conditions of constant transformation of existing knowledge. It were analyzed the main indicators, which characterizing the level of innovative achievements and substantiated the measures for effective co-operation of business subjects. The originality and practical meaningfulness of research is confirmed by the proposed improved mechanism of co-operation of business subjects, which based on a certain level of innovative transformations of all communicating institutions and aimed at achieving national, regional goals and development strategies, which based on global challenges problems. Conclusions and prospects of further researches. It is proved that innovative mechanisms of of cooperation of business subjects should include: economic incentives to encourage effective of communication of business subjects; innovative strategies for initiating measures to unite different companies and institutions; reforms in educational activities for lifelong learning in the real life cycle of of business subjects; extensive infrastructure with stable communication links; prospectus for the provision of intellectual services that determine the level of innovative knowledge of human capital. Further research will focus on establishing and improving partnerships, connections and communications between different businesses.

Key words:

business subjects, knowledge economy, innovations, mechanism of co-operation, transformation.

\section{МЕХАНИЗМЫ ИННОВАЦИОННОГО ВЗАИМОДЕЙСТВИЯ ХОЗЯЙСТВУЮЩИХ СУБЪЕКТОВ В КОНТЕКСТЕ ТРАНСФОРМАЦИИ ЭКОНОМИКИ ЗНАНИЙ}

Постановка проблемы. Успех функционирования современного бизнеса зависит не столько от эффективного использования природных ресурсов сколько от плодотворного взаимодействия между субъектами хозяйствования и своевременного получения необходимой информации по разработке и внедрению в производство новейших технологий, что вызывает необходимость поиска более совершенных механизмов инновационного взаимодействия хозяйствующих субъектов в условиях постоянной трансформации полученных знаний. Цель исследования направлена на разработку инновационных механизмов взаимодействия субъектов хозяйствования путем получения новых знаний в процессе трансформации экономики. Методологической основой исследования стали современные нормативно-правовые и законодательные аспекты осуществления инновационной деятельности. В проведенных исследованиях использованы методы диалектики, способы и принципы научного познания, инструменты экономического анализа для совершенствования механизмов инновационного взаимодействия, получения новой информации и знаний субъектами хозяйствования. Основной гипотезой исследования стало предположение о возможности совершенствования механизма современного взаимодействия субъектов хозяйствования путем заинтересованного объединения всех имеющихся ресурсов, в том числе интеллектуальных, для решения неотложных региональных и национальных проблем. Изложение основного материала. В статье исследуются принципы осуществления инновационной деятельности и указаны основные аспекты, на которых основывается взаимодействие субъектов хозяйствования в условиях постоянной трансформации имеющихся знаний. Проанализированы основные показатели, характеризующие уровень инновационных достижений и обоснованы меры по эффективному взаимодействию субъектов хозяйствования. Оригинальность и практическая значимость исследования подтверждается предложенным усовершенствованным механизмом взаимодействия субъектов хозяйствования, основанным на определенном уровне осуществленных инновационных трансформаций всех взаимодействующих институтов и направлен на достижение общенациональных, региональных целей и стратегий развития, исходя из тех глобальных вызовов, побуждающих решать общемировые человеческие проблемы. Bblводы $u$ перспективы дальнейших исследований. Доказано, что инновационные механизмы взаимодействия субъектов хозяйствования должны включать: экономические стимулы - для поощрения эффективного взаимодействия субъектов; инновационные стратегии, инициирующие мероприятия объединения различных компаний и институтов; реформы в образовательной деятельности, связанные с непрерывным обучением в течении реального жизненного цикла деятельности субъектов хозяйствования; разветвленную инфраструктуру, которая имеет стабильные коммуникационные связи; проспект 
предоставления интеллектуальных услуг, определяющих уровень инновационных знаний человеческого капитала. Дальнейшие исследования будут направлены на налаживание и совершенствование партнерских отношений, связей и коммуникаций между различными субъектами хозяйствования.

\section{Ключевые слова:}

субъекты хозяйствования, экономика знаний, инновации, механизм взаимодействия, трансформация.

Постановка проблеми. Вже неодноразово доведено [1, с. 133], що в сучасних умовах господарювання успіх у бізнесі залежить не стільки від ефективного використання природних ресурсів суб'єктами, скільки від їх плодотворної взаємодії, своєчасного отримання необхідної інформації, розроблення та впровадження у виробництво новітніх технологій, продукування ідей, тощо. Тому можна погодитись із висловленням лауреата Нобелівської премії Д.Б. Шоу, що коли люди в процесі спілкування обмінюються ідеями кожен стає вдвічі багатшим. Звідси виникає потреба у пошуку механізмів інноваційної взаємодії суб'єктів господарювання, які б дозволяли продуктивно використовувати спільно підтримані ідеї та інформацію в процесі своєї діяльності в умовах постійного отримання нових знань.

Аналіз останніх досліджень і публікацій доводять $[1 ; 2 ; 3$, с. 7 - 17; 4; 5], що запорукою успіху $\epsilon$ активна інноваційна діяльність, інтелект, отримані компетентності, вибрані цінності, неординарні методи і моделі взаємодії з різними контрагентами, що створює підгрунтя для генерування нових ефективних методів здійснення діяльності, організації функціонування бізнесу, впровадження нових інноваційних методів господарювання за допомогою наявних знань та дієвих відносин між різними суб' єктами господарювання.

Звідки метою статті $є$ розробка інноваційних механізмів взаємодії суб'єктів господарювання шляхом отримання нових знань в процесі трансформації економіки, що відповідають та задовольняють наявним відношенням між суб'єктами.

Виклад основного матеріалу дослідження. На сьогоднішній день Законом України "Про інноваційну діяльність" [6, ст. 3] визначено наступні принципи проведення державної інноваційної політики:

орієнтація на інноваційний шлях розвитку економіки України;

визначення державних пріоритетів інноваційного розвитку;

формування нормативно-правової бази у сфері інноваційної діяльності; створення умов для збереження, розвитку i використання вітчизняного науковотехнічного та інноваційного потенціалу;

забезпечення взаємодії науки, освіти, виробництва, фінансово-кредитної сфери у розвитку інноваційної діяльності;

ефективне використання ринкових механізмів для сприяння інноваційній діяльності, підтримка підприємництва у наукововиробничій сфері;

здійснення заходів на підтримку міжнародної науково-технологічної кооперації, трансферу технологій, захисту вітчизняної продукції на внутрішньому ринку та іiї просування на зовнішній ринок;

фінансова підтримка, здійснення сприятливої кредитної, податкової і митної політики у сфері інноваційної діяльності;

сприяння розвиткові інноваційної інфраструктури;

інформаційне забезпечення суб'єктів інноваційної діяльності;

підготовка кадрів у сфері інноваційної діяльності.

Із вище викладеного витікає, що інноваційна взаємодія суб'єктів господарювання в умовах сучасного соціально-економічного розвитку України має бути побудована за формулою: знання - можливості - мотивації дієздатність до змін - кінцеві результати.

Показниками, які сьогодні характеризують рівень розвитку інноваційних знань в країні, отримані від цього і ефективність економіки знань $є$ різні індекси, що визначаються різними міжнародними організаціями, в тому числі Світовим банком, Організацією об'єднаних націй і т.п. [7, с. 100, 101; 8, с. 23 - 41]. Так, індекс знань складається з індексів освіти, інновацій, інформаційних технологій і комунікацій, а, наприклад, індекс економіки знань виводиться на основі середніх значень вище вказаних індексів та індексу економічного стимулу та інституційного режиму. Україна зберігає лише 56 позицію і ії стан не змінився майже з 1995 року. Низькі позиції України у наведених рейтингах пов'язані, 3 недосконалим інституційним середовищем, недостатньою увагою до складових економі- 
ки знань. Слід також зазначити, що економічна політика, яка наразі проводиться у державі, не сприяє інноваційному розвитку суб'єктів господарювання. Тому для проведення успішної соціально-економічної трансформації економіки знань необхідно:

створення сприятливого інвестиційного клімату та інвестування, особливо у високотехнологічні виробництва;

розвиток і формування найважливіших ресурсів, що сприяють економічному зростанню;

удосконалення та реформування освітньої діяльності;

створення конкурентних умов для усіх суб'єктів господарювання 3 метою мотивування до інноваційної праці;

формування трудових ресурсів, здатних приймати ефективні рішення в мінливих умовах розвитку національної економіки;

сприяння впровадженню механізму взаємодії тріумвірату освіти, науки та виробництва;

стимулювання гнучкого інституційного середовища, насамперед, галузі державного інноваційного управління.

Наразі, згідно із законодавством України [6, ст. 1] інноваціями слід вважати - новостворені (застосовані) і (або) вдосконалені конкурентоздатні технології, продукцію або послуги, а також організаційно-технічні рішення виробничого, адміністративного, комерційного або іншого характеру, що істотно поліпшують структуру та якість виробництва i (або) соціальної сфери. Проте сучасні наукові дослідження [9, с. 8] застосовують інновації, які більш відповідають потребам суб'єктів господарювання, а саме це інновації, які:

1) базуються на фундаментальних наукових знаннях, результати яких широко застосовуються в національній економіці;

2) грунтуються на наукових дослідженнях, але мають обмежену сферу використання;

3) розроблені з використанням технічних знань, які вже існують і мають обмежену сферу використання;

4) входять до комбінації різних типів знань в одному виробі;

5) використовують новий продукту в різних сферах;

6) являють собою технічно складні новинки;
7) застосовують вже відомі техніки, методи чи методики у новій галузі.

А звідси інноваційну взаємодію суб'єктів господарювання можна розглядати 3 трьох позицій, як: 1) дію, що сприятиме підвищенню конкурентоздатності суб'єктів; 2) процес трансформації наукових досягнень у виробництво; 3) практичне впроваджена в господарську діяльність досвіду в інших галузях.

Виходячи із сучасного національного інноваційного законодавства, котре налічує близько 200 документів, зокрема: норми Конституції України, Господарського кодексу, закони України «Про інноваційну діяльність», «Про пріоритетні напрями розвитку інноваційної діяльності в Україні», «Про інвестиційну діяльність», «Про наукову і науковотехнічну діяльність», «Про спеціальний режим інноваційної діяльності технологічних парків» та інші, проте не встановлює показники для оцінювання рівня залучення інновацій у господарську діяльності. Рівень залучення інновацій в Україні можна знайти тільки за рейтингами та міжнародними оцінками України, такими як:

а) індекс конкурентоспроможності [10], що сприяє легкості пошуку суспільного консенсусу. Україна за цим показником опустилася у 2020 році на одну позицію та стала 55 з 63 країн світу. Для порівняння: США у цьому році опинились на 10 місці, Польща посіла 38 місце, Росія зайняла 45 місце;

б) глобальний інноваційний індекс. Україна у 2020 році покращила цей показник на 2 сходинки у порівнянні з 2019 роком, посівши 45 місце [11]. Поруч з нами такі країни як В'єтнам - 42 місце, Греція - 43, Таїланд - 44, Румунія - 46, Росія - 47, Індія - 48. Очолюють рейтинг Швейцарія, за нею йдуть Швеція, США, Сполучене Королівство та Нідерланди;

в) індекс використання інформаційних и комунікативних технологій. Згідно «Концепції розвитку цифрової економіки та суспільства України на 2018-2020 роки» [12] країна мала зайняти 50 місце перемістившись 3 79 позиції у в порівнянні з 2016 роком;

г) індекс інноваційних здібностей. Саме за цим індексом Україна перебуває на 46-му місці та він показує потенційні можливості стати наявним партнером для інших країн світу [13, с. 19], особливо для європейських, бо проголошений Україною курс на євроінтеграцію вимагає, насамперед реального інноваційного розвитку [10, с. 19]. 
Взаємопов'язаними та доповнюючими складовими розвитку інновацій та економіки знань на сьогодні вважаються [14, с. 96, 98]: 1) якісна і безперервна освіта; 2) економічні стимули та режими, що заохочують до ефективного використання знань в усіх секторах економіки; 3) ефективна інноваційна система взаємовідносин, що об'єднує в єдиний комплекс економіку, науково-дослідницькі центри і навчальні заклади; 4) динамічна інформаційна інфраструктура, яка надає інформаційні та комунікаційні послуги усім суб' єктам господарювання, різним інституціям та населенню; 5) держава як ініціатор і координатор становлення та розвитку економіки знань.

Звідси інноваційну взаємодію суб'єктів господарювання в умовах економіки знань формують такі особливі характеристики як:

1) сприяння створенню, поширенню та використанню знань 3 метою забезпечення зростання і конкурентоспроможності суб'єктів;

2) мають бути не тільки створені, але й продуктивне використані нові знання, що пов'язані 3 напрацюваннями у високотехнологічних галузях, на кшталт широко застосовувати інформаційні та комунікаційні технології;

3) сприяння формуванню можливостей діяти в мережевій структурі та створення певних здатностей для суб'єктів господарюван- ня здійснювати багато транзакцій, що робить більшість 3 них конкуренто недосяжними;

4) створення таких умов співтовариства, які дозволяють оперативно розбирати, аналізувати та приймати рішення щодо забезпечення планування майбутньої діяльності суб' єктів господарювання;

5) включення та розгляд 3 метою застосування у діяльність суб'єктів не тільки нових технологій виробництва, але й весь механізм продукування знань. Тобто в рамках такого співробітництва передбачається взаємодія 3 університетами і організаціями, котрі проводять дослідження і пропонують для запровадження досягнення фундаментальної i прикладної науки та інші розробки.

Таким чином, розвинута економіка знань створює новий формат для інноваційної взаємодії суб' єктів господарювання, що сприяє розвитку всіх сфер виробництва, змінює характер праці, в тому числі людської, на користь творчої та інтелектуальної діяльності та формує інформаційне середовище в рамках кожного суб'єкту господарювання, що сприяє створенню та розповсюдженню нових технологій застосування цифрової економіки в країні.

Виходячи із вищезгаданого, можна схематично уявити такий механізм інноваційної взаємодії суб'єктів господарювання в контексті постійної трансформації економіки знань (рис. 1).

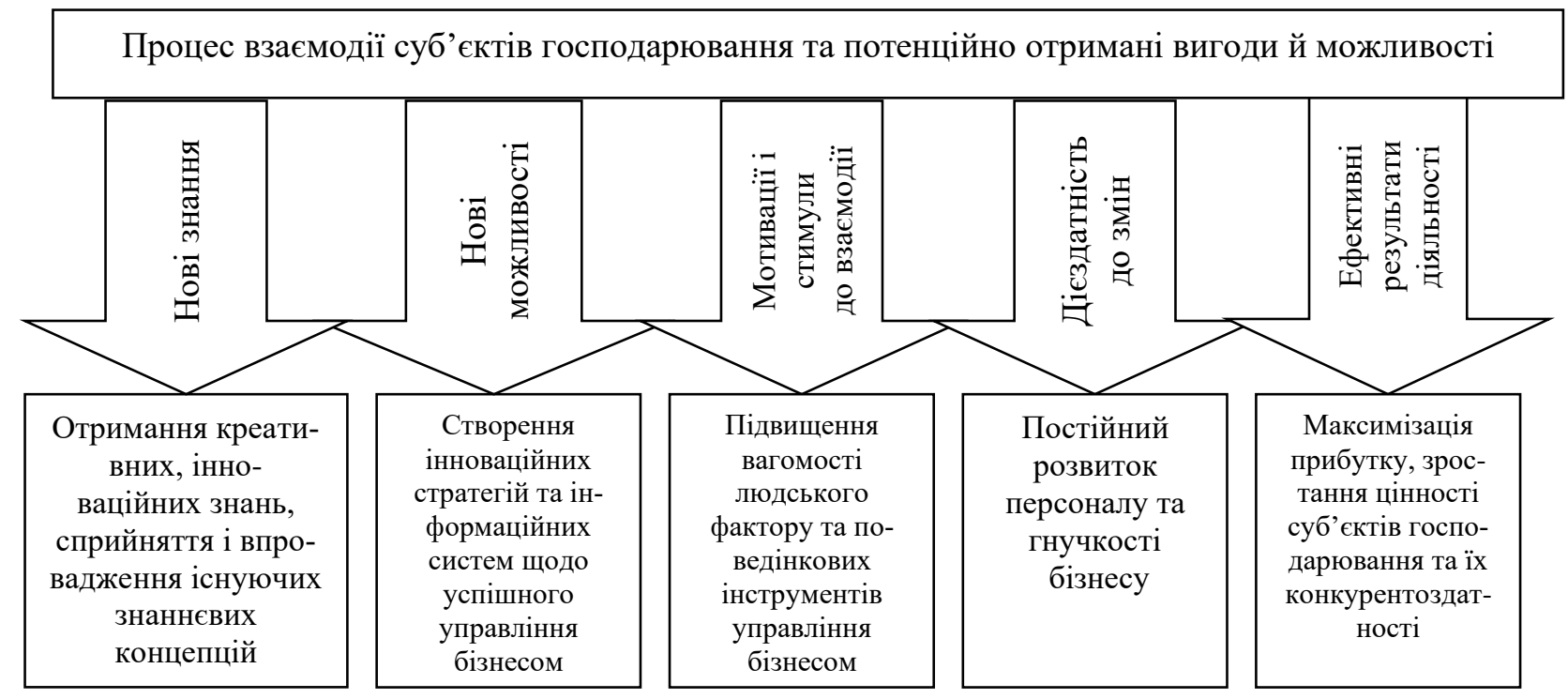

Рисунок 1 - Механізми, перспективи та очікувані наслідки інноваційної взаємодії суб'єктів господарювання Джерело: розроблено автором

Безумовно, на рис. 1 означені найбільш вагомі аспекти, що можна отримати в процесі плідної і зацікавленої взаємодії усіх суб' єктів господарювання. Поза межами залишились: 
процедура вибору суб'єктів для комунікації, сфери зацікавлених зв'язків, налагодження дійсних партнерських відносин та діалогу між різними суб'єктами господарювання, інше, що сьогодні необхідно розвивати та впроваджувати для досягнення загально національних, регіональних цілей і стратегій розвитку, виходячи 3 тих глобальних викликів, що примушують до налагодження спільної праці та вирішення загальносвітових людських проблем, на кшталт боротьби з пандемією на COVID-19.

Висновки та перспективи подальших досліджень. Таким чином, інноваційні механізми взаємодії суб'єктів господарювання в процесі трансформації економіки знань мають включати:

1. Створення дієвих економічних стимулів щодо заохочення ефективної взаємодії та використання знань в усіх аспектах діяльності суб'єктів господарювання;

2. Формування інноваційних стратегій, що ініціюють різні заходи, пов'язані 3 об єднанням та плідною взаємодією різних компаній, наукових та дослідницьких центрів, університетів, банків та інші інституцій;

3. Реформування (трансформування) освітньої діяльності з метою отримання безперервної освіти протягом реального життевого циклу діяльності суб'єктів господарювання та створення необмеженої ресурсної бази, спрямованої на оволодіння цими знаннями;

4. Побудова сучасної інфраструктури, що має забезпечувати комунікаційними зв'язками, доступною високотехнологічною інформацією усі потреби реальної і віртуальної взаємодії суб'єктів господарювання;

5. Розробка заходів щодо зростання інтелектуальних послуг, які характеризують рівень інноваційних знань, котрими володіють суб'єкти господарювання і є основою для створення інноваційного людського капіталу.

Подальші дослідження будуть спрямовані на налагодження дійсних партнерських відносин між різними суб'єктами господарювання для розв'язання і подолання проблемних економічних аспектів, що породжуються глобальними комунікаціями та зв'язками.

\section{Література}

1. Турчіна С. Г. Розвиток економіки знань в умовах інтеграції України до світового господарства. Науковий вісник Ужгород- ського національного університету. Вип. 13, Ч. 2, 2017. С. 133-136.

2. Швиданенко Г. О. Теплюк М. А., Бесараб С. О. Розвиток інноваційного бізнесу в умовах становлення економіки знань. Інвестииії: практика та досвід. 2018. №11. С. 4348.

3. Тищенко В. Ф. Економіка знань як актуальна основа сучасного розвитку України та ї̈ регіонів: монографія. Харків: вид-во ХНЕУ, 2014. $272 \mathrm{c}$.

4. Жарінова А. Г. Розвиток економіки знань в контексті формування людського капіталу. Ефективна економіка. 2013. №11. Режим доступу: http://www.economy.nayka.com.ua/?op=1\&z=253 6

5. Буняк Н. М. Економіка знань як нова форма соціально-економічного розвитку суспільства. Збірник наукових праць Черкаського державного технологічного університету. Серія: Економічні науки. 2012. Вип. 32, Ч. І. C. 59-62.

6. Закон України «Про інноваційну діяльність», 4 липня 2002 р. № 40-IV. Відомості Верховної Ради України. 2002. № 36, ст.266

7. Хусаінов Р. В., Янченко А. Ю., Руденко М. М. Економіка знань: сутність, складові, специфіка. Young Scientist. 2015. № 11(26), November. C. 99-103.

8. Калінеску Т. В., Кирилов О. Д., Фоменко А. О. Оиінювання гнучкості інноващійного розвитку підприємств та виробничого персоналу: монографія. Сєвєродонецьк: видво СНУ ім. В. Даля, 2016. 316 с.

9. Богашко О. Л. Розгляд сутності інновацій в умовах становлення перших теоретичних уявлень про них. Причорноморські економічні студії. Науковий журнал. 2018. Вип. 28. Ч. 1. С. 5-9.

10. Україна втратила одну позицію в рейтингу конкурентоспроможності країн. Режим доступу: https://www.slovoidilo.ua/2020/06/18/novyna/p olityka/ukrayina-vtratyla-odnu-pozycziyurejtynhu-konkurentospromozhnosti-krayin

11. Україна покращила свою позицію в рейтингу «Глобальний інноваційний індекс 2020». Режим доступу: https://www.me.gov.ua/News/Detail?lang=ukUA\&id=edf58f89-c170-4be0-8fc75e7452893639\&title $=$ UkrainaPokraschilaSvoiuP ozitsiiuVReitinguglobalniiInnovatsiiniiIndeks20 20- 
12. Концепції розвитку цифрової економіки та суспільства України на 2018-2020 роки. Схвалено розпорядженням Кабінету Міністрів України від 17 січня 2018 р. № 67-p. Режим доступу: https://zakon.rada.gov.ua/laws/show/672018-\%D1\%80\#Text

13. Сахненко О. I. Економіка знань i державна політика. Науковий вісник Херсонського державного університету. 2014. Вип. 8, Ч. 4.

14. Шульга Ж. О. Особливості економіки знань на сучасному етапі розвитку суспільства. Вісник Бердянського університету менеджменту і бізнесу. 2012. №1(17). С. 9499.

\section{References}

1. Turchina, S. G. (2017). Development of knowledge economy in term of Ukraine integration into the word economy. Scientific Bulletin of Uzhhorod National University. 13, 2, 133 - 136.

2. Shvidanenko, G., Tepliuk, M. and Bessarab, S. (2018). Development of innovative business in becoming a knowledge economy. Investment: Practice and Experience, 11, 43-48.

3. Tystchenko, V. F. (2014). Economy of knowledge as actual basis of modern development of Ukraine and its regions. Kharkiv: Published of Kharkiv National Ecomomical University, 272.

4. Gharinova, A. G. (2013). The development of the knowledge economy in the context of the human capital. Effective economy, 11. Retrieved from: http://www.economy.nayka.com.ua/?op=1\&z=2536

5. Buniak, N. M. (2012). An economy of knowledge as new form of socio-economic development of society. Collection of scientific works of Cherkasy State Technological University. Series: Economic sciences, Scientific, 32, I, 59-62.

6. Law of Ukraine 04.07. 2020, № 40 - IV «About innovative activity», List of Verkhovna Rada of Ukraine (LVR), № 36, p. 266

Стаття надійшла

до редакції : 05.11.2020 p.
7. Khusainov, R. V., Yanchenko, A. Y. and Rudenko, M. M. (2015). Knowledge economy: essence, components, specificity. Young Scientist, 11 (26), 99 - 103.

8. Calinescu, T. V., Kirilov O. D. and Fomenko A. O. (2016). Evaluation of flexibility the innovative development of enterprises and manufacturing personnel. Severodonetsk: Published of Volodymyr Dahl East Ukrainian National University, 316.

9. Bogashko, O. L. (2018). Definition of the term "Innovation" in first scientific theories of innovation development. Black Sea Region Economic Studios. Scientific magazine, 28, 1, 5-9.

10. Ukraine lost one position in rating of countries competitiveness (2020). Retrieved from:

https://www.slovoidilo.ua/2020/06/18/novyna/p olityka/ukrayina-vtratyla-odnu-pozycziyurejtynhu-konkurentospromozhnosti-krayin

11. Ukraine improved the position in rating the «Global innovative index 2020» (2020). Retrieved from: https://www.me.gov.ua/News/Detail?lang=ukUA\&id=edf58f89-c170-4be0-8fc7-

5e7452893639\&title $=$ UkrainaPokraschilaSvoiuP ozitsiiuVReitinguglobalniiInnovatsiiniiIndeks20

12. Conceptions of development the digital economy and society of Ukraine on 20182020 years. (2018). It is approved by the order of Ukraine Cabinet of Ministers, January, 17 № 67p. Retrieved from: https://zakon.rada.gov.ua/laws/show/67-2018$\%$ D1\%80\#Text

13. Sakhnenko, O. A. (2014). Knowledge Economy: Theory and State Policy. Scientific Bulletin of Kherson State University, 8, 4, 16-19.

14. Shulga, J. O. (2012). Features of knowledge economy on the modern stage of society development. Bulletin of the Berdyansk University of Management and Business, 1(17), 94-99.
Стаття прийнята
до друку: 28.12.2020 p.

\section{Бібліографічний опис для цитування :}

Калінеску Т. В. Механізми інноваційної взаємодії суб'єктів господарювання в контексті трансформації економіки знань / Т. В. Калінеску // Часопис економічних реформ. - 2020. - № 4(40). - C. $38-44$. 